Hikmah: Journal of Islamic Studies, 17 (2), 2021, 101-108

http://journal.uinjkt.ac.id/index.php/HIKMAH

DOI: 10.47466/hikmah.v17i2.198. | P-ISSN. 2088-2629, E-ISSN. 2581-0146

\title{
IMPLEMENTASI PENDIDIKAN KARAKTER DI SEKOLAH INKLUSI
}

\author{
Mhd Saleh \\ Sekolah Tinggi Agama Islam Al Hikmah Jakarta, Indonesia \\ mhdsaleh78@gmail.com
}

\begin{abstract}
Through this research, the researcher aimed to analyze and integrate the character education strategy in Sumbersari Primary School 1 Kota Malang and Muhammadiyah Primary School 04 Kota Batu, to become a mixed character education strategy that includes morals knowledge, moral love and moral action. The results of this study indicate that the moral knowledge strategy includes: psychological testing when students want to go to school, planning character education through RPP, transmission of character values through the method of course, character information, extracurricular activities and assessment carried out with the student's character assessment sheets or through tortuous activities. Although the moral strategy of love is achieved through a teacher or character, extracurricular activities, visits to inspiring places such as a hero's grave, character films, 'peer therapy, religious activities and punishment activities that arouse students. While moralizing strategies such as helping each other, collecting trash together and pointing fingers, going to class with your right foot and praying, praying when you start the lesson, speaking and being polite, and pray together.
\end{abstract}

Keywords: character education; inclusion school

\begin{abstract}
Abstrak
Penelitian ini menganalisis dan menggabungkan strategi pendidikan karakter yang ada di sekolah inklusif yaitu SDN Sumbersari 1 Kota Malang dan SD Muhammadiyah 04 Kota Batu, menjadi strategi penanaman karakter gabungan yang meliputi pengetahuan moral, cinta moral dan tindakan moral. Kajian menunjukkan bahwa strategi penanaman pengetahuan moral meliputi: tes psikologi ketika siswa akan masuk sekolah, perencanaan pendidikan karakter melalui RPP, penanaman nilai karakter proses atau metode pembelajaran, informasi tentang karakter, kegiatan ekstrakurikuler dan penilaian yang dilakukan dengan lembar evaluasi karakter siswa, maupun melalui kegiatan kelompok. Sedangkan cinta moral dilakukan melalui wibawa dan tindakan guru atau inspirasi tokoh teladan, kegiatan ekstrakurikuler, kunjungan ke tempat-tempat yang merangsang seperti Makam Pahlawan, menonton film karakter, kegiatan terapi sebaya, kegiatan keagamaan dan hukuman yang menyadarkan siswa. Adapun pembiasan tindakan moral dilakukan seperti gotong royong, mengumpulkan sampah secara bersama-sama dan berkala, masuk kelas dengan kaki kanan dan memanjatkan doa, memulai kelas pembelajaran dengan berdoa, berbicara dan berperilaku santun, sholat dhuha dan zuhur berjamaah.
\end{abstract}

Kata Kunci: pendidikan karakter; sekolah dasar inklusi 


\section{PENDAHULUAN}

Sekolah harus mampu mentransfer nilai-nilai budi pekerti kepada siswa untuk menjadi apresiatif, suportif, siap bekerja sama dan lebih toleran terhadap pluralisme yang ada. Namun kenyataannya, banyak sekolah yang mengedepankan keterampilan saja dan meninggalkan penanaman sikap (soft skills), sedangkan soft skills merupakan unsur yang membentuk karakter siswa. Hal ini sejalan dengan pendapat Zubaedi yang menyebutkan bahwa pendidikan di Indonesia lebih menitikberatkan pada pengembangan intelektualitas, sedangkan aspek nonakademik yang merupakan unsur utama pembentukan karakter itu tidak dioptimalkan. ${ }^{1}$

Transfer nilai moral lebih banyak terletak pada teori pemahaman melalui penjelasan, sedikit dilakukan pembiasaan karakter di lingkungan sekolah. Inilah salah satu penyebab mengapa banyak siswa Sekolah Dasar tidak mencerminkan akhlak yang baik dalam tindakannya seperti; tidak peduli, susah menerima keberagaman, tindak kekerasan, perundungan, rendahnya tanggung jawab serta ketidakpercayaan dan kebencian antar sesama siswa. ${ }^{2}$ Permasalahan tersebut tidak lepas dari kurangnya dominasi afektif pembentukan karakter di sekolah.

Pendidikan karakter yang dilakukan dalam dunia pendidikan dapat menjadi sarana dan upaya untuk meningkatkan kualitas akhlak siswa sehingga membuat masyarakat merasa lebih bersahabat. ${ }^{3}$ Bahwa sekolah juga menjadi tempat mempengaruhi nilai-nilai moral siswa melalui pendidikan karakter, ${ }^{4}$ Terutama di sekolah dasar. Pendapat banyak ahli bahwa proporsi pendidikan karakter di sekolah dasar bisa mencapai lebih dari 60\%, sehingga nilai-nilai karakter tersebut dapat tertanam dan ditumbuhkan sampai siswa dewasa. ${ }^{5}$ Lembaga pendidikan seperti sekolah dasar, termasuk sekolah inklusi, harus menyadari hal tersebut dan menjadikan sekolah sebagai tempat penanaman akhlak mulia siswa. Siswa tidak direspon berbeda berdasarkan kondisi fisik dan kebutuhannya. ${ }^{6}$

\footnotetext{
2011), h. 3.

${ }^{1}$ Zubaedi, Desain Pendidikan Karakter: Konsepsi dan Aplikasinya dalam Lembaga Pendidikan (Jakarta: Kencana,

${ }^{2}$ Abusiri, "Media Pembelajaran dan Upaya Membangun Kesadaran Belajar Siswa," Hikmah: Journal of Islamic Studies, Vol. 13, No. 12017, h. 36-64 https://doi.org/10.47466/hikmah.v13i1.81. Thomas Lickona, Educating For Character, terj. Juma Abdu Wamanungo, Mendidik untuk Membentuk Karakter: Bagaimana Sekolah dapat Memberikan Pendidikan tentang Sikap Hormat dan Tanggung Jawab (Cet. 4: Jakarta: Bumi Aksara, 2012), h. 12-14

${ }^{3}$ Doni Koesoema A, Pendidikan Karakter: Strategi Mendidik anak di Zaman Global (Jakarta: Grasindo, 2010), h. 116

${ }^{4}$ Novan Ardy Wiyani, Manajemen Pendidikan Karakter: Konsep dan Implementasinya di Sekolah (Yogyakarta: Pedagogia, 2012), h. 98.

${ }^{5}$ Sofan Amri, dkk, Implementasi Pendidikan Karakter dalam Pembelajaran "Strategi Analisis dan Pengembangan Karakter Siswa dalam Proses Pembelajaran (Jakarta: Prestasi Pustaka, 2011), h. 50.

${ }^{6}$ Hargio Santoso, Cara Memahami dan Menididk Anak Berkebutuhan Khusus (Yogyakarta: Gosyen Publishing, 2012), h. 18.
} 


\section{METODE}

"Penelitian ini merupakan penelitian studi kasus, jenis penelitian kualitatif. Penelitian ini menganalisis strategi pembentukan karakter yang dilakukan di kedua sekolah. Studi kasus ini menemukan, dan merumuskan sumber data penelitian berupa wawancara, observasi dan analisis dokumentasi yang berhubungan dengan pembentukan karakter di kedua sekolah tersebut. Merumuskan penjelasan dari hasil wawancara. Mengamati proses pelaksanaan pendidikan inklusi di kedua sekolah ini. Menganalisis dokumentasi dapat berupa telaah dokumen terkait pendidikan inklusi di" sekolah; seperti dokumen proses pelaksanaan pembelajaran di kelas, RPP untuk guru, visi misi sekolah, atau pendukung lainnya. Studi kasus ini mengkaji ide dan tujuan, persepsi, pendapat orang dan segala sesuatu yang tidak dapat diukur dengan angka. ${ }^{7}$

"Pengkajian ide, persepsi, pendapat mencakup pengkajian data yg dihasilkan berdasarkan melalui wawancara, observasi \& analisis dokumentasi terhadap managemen sekolah, guru, komite ataupun murid yg dituangkan pada bentuk perencanaan jangka panjang atau jangka pendek mengenai pendidikan karakter di Sekolah Dasar Negeri Sumbersari 1 Kota Malang \& Sekolah Dasar Muhammadiyah 04 Kota Batu. Pengamatan tindakan dan keputusan pimpinan sekolah, guru, komite $\&$ murid pada melaksanakan pendidikan karakter."

\section{PEMBAHASAN}

\section{Pengetahuan Moral di Sekolah Dasar Inklusi}

Pengetahuan moral bagi siswa normal dan siswa yang memiliki kebutuhan khusus di SDN Sumbersari 1 Kota Malang diwujudkan melalui beberapa tahapan;

1. Melakukan psikotes ketika pendaftaran sebagai langkah pengetahuan awal guru dan management sekolah tentang kebutuhan siswa yang berkebutuhan khusus hal ini sesuai dengan pendapat Zubaedi tentang pentingnya pendidikan karakter yang terus menerus dimulai dari awal masuk sampai lulus.

2. Menyisipkan rencana pembelajaran karakter pada rencana proses pembelajaran. Thomas berpandangan bahwa pendidikan moral harus di bangun dan disesuikan dengan kurikulum.' Sejalan juga dengan pendapat agus W bahwa penanaman

\footnotetext{
${ }^{7}$ Maleong, Lexi J, Metodologi Penelitian Kualitatif (Bandung: PT Remaja Rosdakarya, 2005), h. 4

${ }^{8}$ Zubaedi, Desain Pendidikan Karakter: Konsepsi dan Aplikasinya dalam Lembaga Pendidikan, h. 138

${ }^{9}$ Thomas Lickona, Educating For Character, terj. Juma Abdu Wamanungo h. 244
} 
karakter melalui integrasi kurikulum, pengembangan keterampilan, dan budaya sekolah. ${ }^{10}$

3. Integrasi materi pembelajaran karakter dengan materi pembelajaran. Integrasi ini dengan berkelanjutan dan penuh kesadara guru bahwa setiap materi pelajaran dapat dijelaskan bersamaan dan berkaitan dengan pengetahuan karakter di dalamnya

4. Papan Informasi karakter atau mading karakter ini juga sebagai transfer pengetahuan moral dengan tidak terstruktur, setiap siswa berjalan dan melihat mading karakter ini dengan sendirinya pengetahuan karakter ditransfer kepada siswa, "hal ini diperkuat dengan pendapat Sri Narwanti. yang menjelaskan bahwa penerapan pendidikan karakter di sekolah dasar terjadi dalam proses pembelajaran, dalam pengembangan budaya sekolah dan di pusat kegiatan pembelajaran, di dalam kurikulum dan di area ekstrakurikuler. ${ }^{11}$

5. Materi karakter pada pembelajaran dan materi yang disampaikan di kegiatan ekstrakurikuler juga menjadi sesuatu yang pokok, selain keterampilan yang diasah, afektif siswa juga perlu dibangun untuk dapat menjalankan keterampilan mereka setelah mengikuti kegiatan esktrakurikuler. Kegiatan ekstrakurikuler yang di dua sekolah tersebut cukup banyak, diantaranya: karate, bela diri tapak suci, pramuka, hisbul wathan (kegiatan kepanduan di sekolah swasta Muhammadiyah, tahfizh Al Qur'an, kegiatan seni tradisional jawa timur, kegiatan seni mewarnai dan menggambar dan kegiatan lainnya.

6. Terapi sebaya yang di terapkan di kedua sekolah ini sebagai bentuk upaya pembentukan ekosistem pendidikan karakter di kedua sekolah itu.

7. Kegiatan bercerita dan mendongeng menjadi metode untuk mendukung pelaksanaan pendidikan karakter di sekolah, karena di dalam cerita terdapat berbagai contoh dan memiliki dampak psikologis pada siswa. ${ }^{12}$ Menurut Yuhelmi, penggunaan metode mendongeng dalam pembelajaran karakter memang membuahkan hasil yang positif. Metode ini dapat mengembangkan nilai karakter pada siswa, perkembangan emosi siswa, dapat mengembangkan kemampuan berbahasa, perkembangan kognitif, keterampilan motorik dan kreativitas siswa. ${ }^{13}$ Menurut Thomas, kehidupan moral di kelas melatih siswa menghadapi konflik. Ada 5 hal yang dapat dilakukan guru guru dalam melatih

\footnotetext{
${ }^{10}$ Agus Wibowo, Pendidikan Karakter Strategi Membangun Karakter, h. 83.

${ }^{11}$ Sri Narwanti, Pendidikan Karakter (Yogyakarta: Grup Relasi inti Media, 2011). h. 53.

${ }^{12}$ Heri Gunawan, Pendidikan Karakter Konsep dan Impementasi, h. 20.

${ }^{13}$ Yuhelmi, "Pendidikan Karakter Anak Usia Dini Melalui Strategi Mendongeng Cerita Budaya Daerah Minangkabau, Jurnal PEDAGOGI “(Volume XIV No.2 November 2014), h. 59-60.
} 
siswanya, yaitu: 1) kurikulum yang direncanakan, 2) pelatihan keterampilan penyelesaian konflik, 3) menggunakan musyawarah dalam menyelesaikan konflik diantara siswa, 4) campur tangan seperlunya untuk membantu siswa menerapkan keterampilan intrapersonal mereka ketika konflik baru muncul, 5) membuat siswa merasa lebih bertanggung jawab. ${ }^{14}$

8. Evaluasi pengetahuan karakter diterapkan melalui lembar penilaian siswa dan tindakan yang telah mereka lakukan karena siswa tersebut diajari untuk menilai karakter mereka sendiri. Evaluasi ini menjadi penilaian yang sangat penting pada tahapan pengetahuan moral. Hasil dari evaluasi ini menjadi bahan bagi guru dalam mengembangkan dan memperbaiki penanaman pengetahuan moral di kedua sekolah ini.

\section{Cinta Moral di Sekolah Dasar Inklusi}

Cinta moral adalah tahapan pendidikan karakter pokok di kedua sekolah, tahapan ini menjadi bagian yang sangat penting yang menyentuh afektif siswa, fase ini di lakukan melalui proses yaitu;

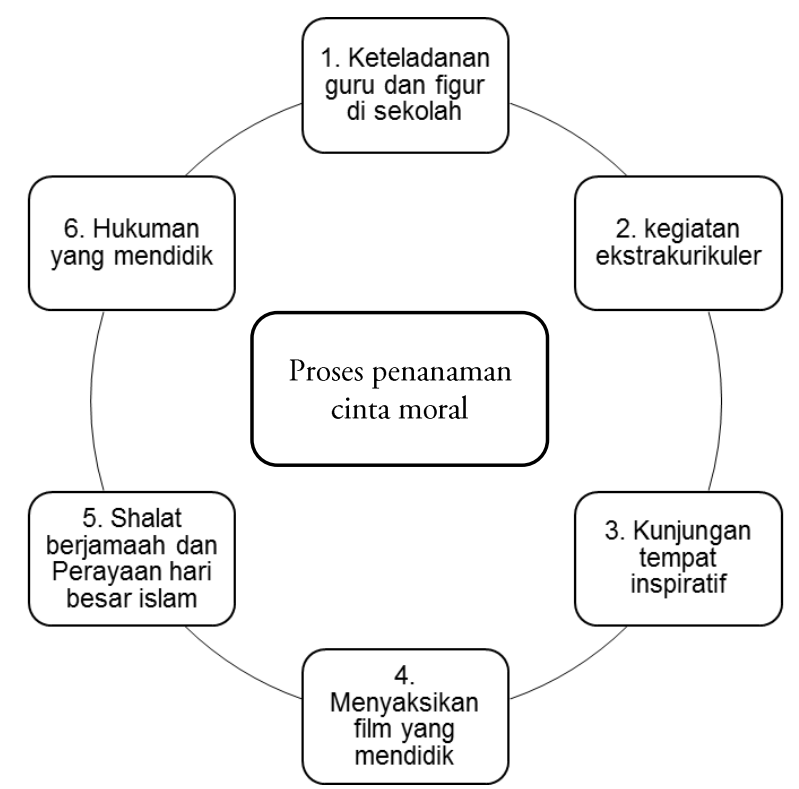

Keteladanan guru sangat berpengaruh signifikan terhadap karakter siswa, hal ini karena usia siswa masih mempengaruhi cara belajar nya yaitu mencontoh dan meniru. Cinta moral ditanamkan juga melalui kegiatan ekstrakurikuler. Melalui kegiatan ini siswa diajarkan bahwa tujuan kegiatan mereka adalah untuk melindungi diri dan orang lain yang lemah. Prinsip ini menjadikan sesama siswa peduli satu sama lain. Kunjungan tempat inspirati seperti makam pahlawan juga membawa pengaruh positif terhadap siswa, sama halnya

${ }^{14}$ Thomas Lickona, Educating For Character, terj. Juma Abdu Wamanungo, h. 410-412 
dengan kegiatan menonton film karakter yang mendidik sangat signifikan mempengaruhi psikologis siswa. Kegiatan peringatan hari besar islam juga menjadi tahapan yang penting bagi kedua sekolah ini, ini memberikan informasi bagi mereka tentang kehidupan Nabi Muhammad (diantaranya) dan dapat menumbuhkan cinta terhadap beliau dan terhadap keteladanan beliau. Memberi hukuman yang mendidik terhadap siswa yang melanggar peraturan dan etika sekolah; berperan signifikan dalam penanaman cinta moral ini kepada siswa, karena siswa merasakan hukuman yang diberikan juga mendidik mereka dan membiasakan mereka melakukan hal-hal yang baik. Yang menjadi perhatian penting sekolah adalah menyamakan persepsi antara guru akan pentingnya memberi hukuman yang mendidik. ${ }^{15}$

\section{Tindakan Moral di Sekolah Dasar Inklusi}

Fase pendidikan karakter di sekolah inklusif selanjutnya adalah pembiasan tindakan moral, diantaranya membersihkan pengarangan sekolah dan mengumpulkan sampah secara bersama; guru dan siswa secara teratur. Memasuki kelas dengan melangkahkan kaki kanan sambil berdoa, memulai pembelajaran dengan berdoa, disiplin membiasakan diri untuk bertutur kata yang sopan dan santun, baik sesama siswa maupun guru ke siswa, saling menyapa ketika bertemu, shalat berjamaah, shalat dhuha, meletakkan barang pada tempatnya dengan disiplin. Pembiasaan yang sederhana ini menjadi faktor pembentuk karakter siswa di dua sekolah tersebut, dan ini mempengaruhi kebiasaannya pada hal-hal yang lebih kompleks. Amalan ini merupakan tujuan akhir dari pendidikan karakter, karena karakter bertujuan untuk membentuk pemikiran, sikap dan perilaku siswa, sehingga menjadikan mereka pribadi yang aktif, berakhlak mulia, dan bertanggung jawab.

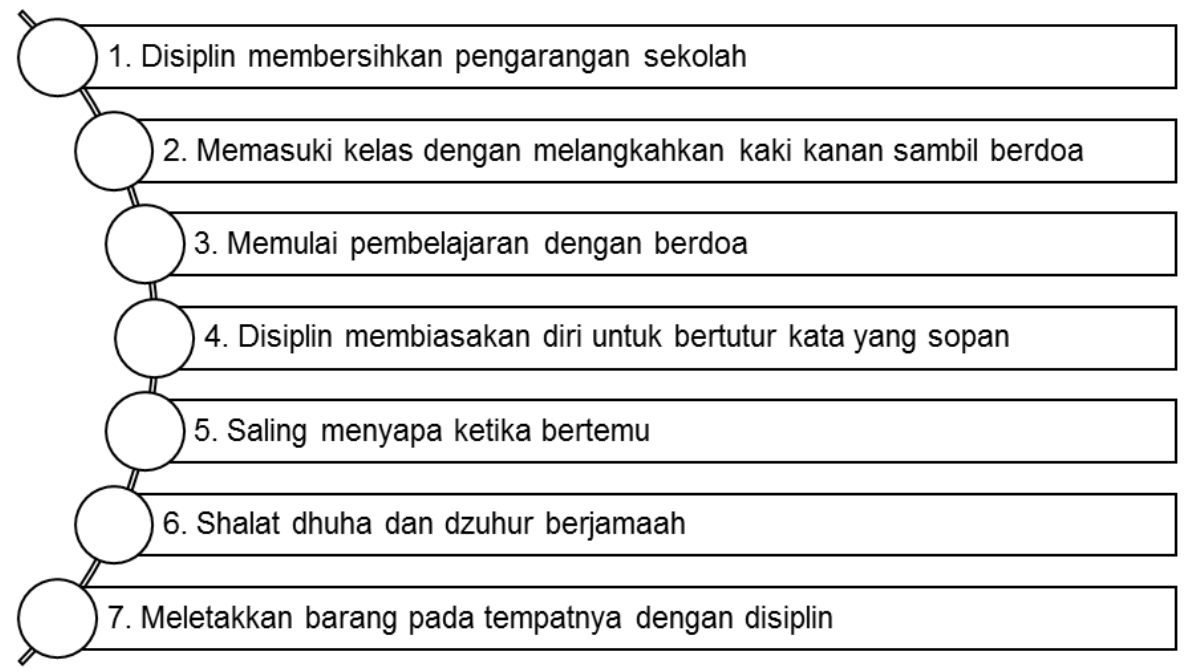

\footnotetext{
${ }^{15}$ Thomas Lickona, Educating For Character, terj. Juma Abdu Wamanungo, h. 179
} 


\section{PENUTUP}

Strategi penanaman karakter di sekolah inklusif dapat disimpulkan melalui penelitian ini yaitu di bagi ke dalam 3 tahapan: pertama, Pengetahuan moral "dapat dipahami sebagai strategi atau upaya yang terfokus pada guru agar siswa menguasai pengetahuan karakter (kognitif) baik untuk siswa berkebutuhan khusus maupun siswa reguler melalui langkahlangkah sebagai berikut : melakukan tes psikologi pada saat siswa mendaftar di sekolah, dengan tes ini, sekolah dapat menawarkan atau merencanakan program sekolah dengan kebutuhan khusus siswa. Penanaman nilai karakter juga diintegrasikan melalui perencanaan guru (RPP) melalui metode pembelajaran seperti mendongeng, nilai demokratis secara individual, melalui papan informasi di dinding sekolah. Juga dapat diajarkan melalui ekstrakurikuler, seperti bela diri tapak suci, karate, kesenian, pramuka, hizbul wathan atau sejenisnya. Sedangkan penilaian dapat dilakukan dengan lembar penilaian karakter siswa. Penilaian ini bisa secara individual ataupun melalui kegiatan kelompok seperti sosiodrama dan terapi sebaya atau pembelajaran kooperatif lainnya". Kedua, Cinta moral "dapat dipahami sebagai fase penanaman karakter yang menyadarkan siswa tentang pentingnya nilai-nilai karakter dan siswa dapat menyadari bahwa dirinya memiliki karakter yang baik atau tidak bagi lingkungannya yaitu guru, siswa reguler dan siswa dengan kebutuhan khusus. Strategi penanaman cinta moral ini dapat berupa contoh guru atau keteladanan figur, kegiatan ekstrakurikuler, mengunjungi tempat-tempat yang memberi inspirasi seperti makam pahlawan, dengan menonton film, kegiatan terapi sebaya, kegiatan rutin keagamaan; sholat berjamaah dan peringatan hari besar Islam, memberikan punishment dengan menyadarkan siswa akan pentingnya nilai-nilai karakter seperti memungut sampah apabila berkata kasar, mendongeng apabila terlambat dan lain-lain”. Ketiga, Tindakan Moral "merupakan fase penanaman karakter yang dapat dilakukan di sekolah inklusif. Strategi membuat peraturan dan melaksanakannya, seperti saling membantu melalui program terapi sebaya, apel sampah yaitu mengambil sampah secara bersama dan teratur, masuk kelas dengan menggunakan kaki kanan dan berdo'a, berdo'a ketika memulai pembelajaran, berkata dan bersikap yang sopan, shalat Dhuha dan Zuhur bersama-sama, menyusun barang pada tempatnya”.

Faktor pendukung dan penghambat penanaman karakter di SD inklusif merupakan sisi lain di luar strategi penanaman karakter. Faktor pendukung dapat hadir dari guru dan pegawai yang sudah berpengalaman, guru yang mendampingi siswa berkebutuhan khusus (shadow), organisasi keagamaan di luar sekolah seperti Muhammadiyah, pengawasan dan dorongan dari pimpinan sekolah sekolah, perhatian pemerintah kota, kegiatan siswa berupa ekstrakurikuler, siswa reguler dan termasuk siswa yang berkebutuhan khusus. Sedangkan faktor penghambat penanaman karakter di sekolah inklusif termasuk fasilitas sekolah yang belum memadai sehingga pelayanan sekolah kepada siswa reguler dan siswa berkebutuhan 
khusus belum maksimal, siswaitu sendiri diantaranya siswa yang memiliki gangguan emosi, dan pemahaman orang tua terhadap program sekolah.

\section{DAFTAR PUSTAKA}

Abusiri, 2017. "Media Pembelajaran dan Upaya Membangun Kesadaran Belajar Siswa," Hikmah: Journal of Islamic Studies, Vol. 13, No. 1.

Amri, Sofan dkk., 2011. Implementasi Pendidikan Karakter dalam Pembelajaran "Strategi Analisis dan Pengembangan Karakter Siswa dalam Proses Pembelajaran. Jakarta: Prestasi Pustaka,

Ardy Wiyani, Novan. 2012., Manajemen Pendidikan Karakter: Konsep dan Implementasinya di Sekolah. Yogyakarta: Pedagogia.

Gunawan, Heri. 2012. Pendidikan Karakter Konsep dan Impementasi. Bandung: Alfabeta.

Koesoema A, Doni. 2010. Pendidikan Karakter: Strategi Mendidik anak di Zaman Global. Jakarta: Grasindo.

Lickona, Thomas. 2012. Mendidik untuk Membentuk Karakter: Bagaimana Sekolah dapat Memberikan Pendidikan tentang Sikap Hormat dan Tanggung Jawab (Penerjemah: Juma Abdu Wamanungo), Jakarta: Bumi Aksara.

Maleong, Lexi J. 2005. Metodologi Penelitian Kualitatif. Bandung: PT Remaja Rosdakarya.

Narwanti, Sri. 2011. Pendidikan Karakter. Yogyakarta: Grup Relasi inti Media,

Santoso, Hargio. 2012. Cara Memahami dan Menididk Anak Berkebutuhan Khusus. Yogyakarta: Gosyen Publishing.

Wibowo, Agus. 2012. Pendidikan Karakter Strategi Membangun Karakter Bangsa Berperadaban. Yogyakarta: Pustaka Pelajar.

Yuhelmi. 2014. "Pendidikan Karakter Anak Usia Dini Melalui Strategi Mendongeng Cerita Budaya Daerah Minangkabau”, Pedagogi: Jurnal Ilmiah Ilmu Pendidikan Volume XIV No.2 November 2014. Universitas Negeri Padang.

Zubaedi. 2014. Desain Pendidikan Karakter: Konsepsi dan Aplikasinya dalam Lembaga Pendidikan. Jakarta: Kencana. 